\title{
O.V. Tsisar ${ }^{1}$, L.V. Piskach ${ }^{1}$, O.V. Parasyuk ${ }^{1}$, O.V. Zamurujeva ${ }^{1}$, G.L. Myronchuk ${ }^{1}$, M. Piasecki ${ }^{1,2}$ \\ $\mathrm{Tl}_{2} \mathrm{~S}-\mathrm{In}_{2} \mathrm{~S}_{3}-\mathbf{G e S}_{2}$ Glass System as Novel Promising Materials for Photonics
}

\author{
${ }^{1}$ Lesya Ukrainka Eastern European National University, Lutsk, Ukraine, oksana_tsisar@i.ua, piskach.lyudmyla@eenu.edu.ua, \\ zamurueva.o@gmail.com, myronchuk.halyna@eenu.edu.ua \\ ${ }^{3}$ Institute of Physics, J. Dlugosz University in Czestochowa, Czestochowa, Poland, piaseckimw@gmail.com
}

\begin{abstract}
It was established that minimal content of the glass-forming component $\mathrm{GeS}_{2}$ is equal to $30 \mathrm{~mol} \%$ (by exploration the set of 23 different alloys with different composition). Correlation between structural properties, thermal parameters (glass transition, crystallization and melting temperatures) and optical absorption spectra along of the titled glasses system has been found. The temperatures, the band gap energy and the characteristic energy of vitreous alloys for the gastric system $\mathrm{Tl}_{2} \mathrm{~S}-\mathrm{In}_{2} \mathrm{~S}_{3}-\mathrm{GeS}_{2}$ were investigated experimentally.
\end{abstract}

Keywords: chalcogenide glasses; optical properties; XRD diffraction patterns.

Стаття поступила до редакиії 19.11.2019; прийнята до друку 15.12.2019.

\section{Introduction}

Third-order non-linear optical materials are recently explored very intensively researched in the recent years due to the prospect of their use in ultra-high speed switcher, triggers, light modulators, deflectors et. for optical communications [1-4]. These materials include chalcogenide glasses which have relatively high refractive indices, wide transparency spectral range, and high thermal and chemical resistance [4]. Although generally chalcogenide glasses are isotropic, they may possess promising photoinduced [5], photonics [6] and nonlinear optical [7] properties.

For instance, we have earlier demonstrated in ref. [2] the possibility of using the $\mathrm{Tl}_{2} \mathrm{~S}-\mathrm{Ga}_{2} \mathrm{~S}_{3}-\mathrm{GeS}_{2}$ glasses as materials for effective photoinduced third harmonic generation described by fourth rank tensors. The glassformation region in this system determined by quenching the melts from $1300 \mathrm{~K}$ is quite significant, the concentration of the glass-forming agent $\mathrm{GeS}_{2}$ is varied within the $30-100 \mathrm{~mol} . \%$. Here we present the study of the glass formation for similar glass system $\mathrm{Tl}_{2} \mathrm{~S}-\mathrm{In}_{2} \mathrm{~S}_{3}-\mathrm{GeS}_{2}$ together with the optical properties of the obtained glasses. Glass formation in the quasi-ternary systems based on the $\mathrm{In}_{2} \mathrm{~S}_{3}-\mathrm{GeS}_{2}$ side was studied in [2].
In particular, the region of the existence of glassy alloys in the $\mathrm{GeS}_{2}-\mathrm{Sb}_{2} \mathrm{~S}_{3}-\mathrm{In}_{2} \mathrm{~S}_{3}$ system determined by quenching from $1223 \mathrm{~K}$ is relatively narrow and is extended along the $\mathrm{GeS}_{2}-\mathrm{Sb}_{2} \mathrm{~S}_{3}$ side. The maximum $\mathrm{In}_{2} \mathrm{~S}_{3}$ content does not exceed $15 \mathrm{~mol} \%$, and the content of $\mathrm{Sb}_{2} \mathrm{~S}_{3}$ reaches about $90 \mathrm{~mol} . \%$. It was established that these glasses can be used in various optoelectronic and photonic devices effectively operating in the mid-IR range. The glass-formation region with potassium chloride as one of the modifiers $\left(\mathrm{GeS}_{2}-\mathrm{In}_{2} \mathrm{~S}_{3}-\mathrm{KCl}\right)$ is located in a space enriched with $\mathrm{GeS}_{2}$ and extending from the $\mathrm{GeS}_{2}$ corner down to $\sim 50 \mathrm{~mol} . \% \mathrm{KCl}$ at a fixed molar ratio of $\mathrm{In}_{2} \mathrm{~S}_{3} / \mathrm{KCl} 1: 2$. The minimum $\mathrm{GeS}_{2}$ concentration is equal to $35 \mathrm{~mol} \%$ [8]. In a similar system involving $\mathrm{CsCl}$. The location of the glass-forming region is similar, with a minimum glass-forming agent concentration equal to about $15 \mathrm{~mol} \%$ [9].

\section{Setting the problem}

Phase equilibria in the $\mathrm{In}_{2} \mathrm{~S}_{3}-\mathrm{GeS}_{2}$ system were studied in ref. [2]. The phase diagram is of eutectic type with additional invariant horizontal lines associated with $\mathrm{In}_{2} \mathrm{~S}_{3}$ phase transitions. The existence of the $\operatorname{In}_{16} \mathrm{Sn}_{4} \mathrm{~S}_{32}$ 
compound with the spinel structure (SG $F \mathrm{~d}-3 \mathrm{~m}$, $a=1.07551 \mathrm{~nm}$ ) was reported in ref. [10]. The formation of this phase can be explained within a framework of $\beta$ $\mathrm{In}_{2} \mathrm{~S}_{3}$ stabilization. Glass formation in the Ge-In-S system was investigated in [9]. The $\mathrm{Tl}_{2} \mathrm{~S}-\mathrm{In}_{2} \mathrm{~S}_{3}-\mathrm{GeS}_{2}$ glasses were obtained by vacuum synthesis (at $10^{-7}$ Tor) from the high purity elements, with quenching into ice-cold saline from $1273 \mathrm{~K}$ (for glasses with low sulphur content) or $1073 \mathrm{~K}$ (for sulphur-rich glasses) up to 15 at.\% which could be incorporated into the glasses under such synthesis and cooling conditions. The glasses with higher sulphur content are transparent. Occurrence of yellow colour, darkening to red and black is observed with increasing germanium content. Glass transition temperature $T_{g}$ in the Ge-In-S system is significantly lower than in the $\mathrm{Ge}-\mathrm{Ga}-\mathrm{S}$ system and is varied from $573 \mathrm{~K}\left(\operatorname{In}_{5} \mathrm{Ge}_{42.7} \mathrm{~S}_{52.3}\right)$ to $383 \mathrm{~K}\left(\operatorname{In}_{10} \mathrm{Ge}_{9} \mathrm{~S}_{81}\right) . \mathrm{T}_{\mathrm{g}}$ increases with germanium content, while the change in indium concentration has only little effect. All the glasses are stable in air.

The glass-formation region for the $\mathrm{GeS}_{2}-\mathrm{In}_{2} \mathrm{~S}_{3}$ system, according to [10], exists in the range of $0-30$ mol. $\% \mathrm{In}_{2} \mathrm{~S}_{3}$. The glass transition temperature in the same work is reported within the temperature region $622-733 \mathrm{~K}$. The crystallization of the glasses containing 80 and 70 mol.\% $\mathrm{GeS}_{2}$ is described by two exothermal effects (the first one is varied between $698-818 \mathrm{~K}$, the second one $-814-828 \mathrm{~K}$ ). The first peak is likely due to the crystallization of $\beta-\operatorname{In}_{2} S_{3}$, the second reflects the crystallization of $\mathrm{GeS}_{2}$. The melting point $\left(\mathrm{T}_{\mathrm{m}}\right)$ of the studied glasses is in the range of $1007-1090 \mathrm{~K}$. The analysis of the criteria for thermal stability indicates high glass-forming ability and possibility to obtain optical fibers from these glasses. The values of characteristic temperatures decrease with increasing $\operatorname{In}_{2} \mathrm{~S}_{3}$ content which may be related to the formation of the eutectic in the $\mathrm{GeS}_{2}-\mathrm{In}_{2} \mathrm{~S}_{3}$ system. And additionally it may be caused by the change in the order of the formation of the structural units of glass. The structure of the glasses of the Ge-In-S system was studied by Raman and IR spectroscopy [11, 12]. Main structural units of the glasses are $\left[\mathrm{GeS}_{4}\right]$ tetrahedra are connected by corners and edges, $\left[\mathrm{InS}_{4}\right]$ tetrahedra and $\left[\mathrm{InS}_{6}\right]$ octahedra are connected by sulphide bridges. Non-linear optical properties of the several types of the chalcogenide glasses confirm that they can be used as promising materials for optical commutation devices.

The $\mathrm{Tl}_{2} \mathrm{~S}-\mathrm{GeS}_{2}$ system features the $\mathrm{Tl}_{4} \mathrm{GeS}_{4}, \mathrm{Tl}_{2} \mathrm{GeS}_{3}$ and $\mathrm{Tl}_{2} \mathrm{Ge}_{2} \mathrm{~S}_{5}$ compounds which melt congruently at $677 \mathrm{~K}, 763 \mathrm{~K}$ and $868 \mathrm{~K}$. The last two compounds may be obtained both in crystalline and glassy state. Glass formation in the $\mathrm{Tl}-\mathrm{Ge}-\mathrm{S}$ system using quenching in air allows over 30 at.\% Thallium in the composition of the glassy alloys. It was established that their thermal stability is significantly reduced with increasing $\mathrm{Tl}$ content. The value of the glass transition temperature decreases from 593 to $463 \mathrm{~K}$. The results of DTA of the glasses of the $\mathrm{Tl}_{2} \mathrm{~S}-\mathrm{GeS}_{2}$ system shown that the addition of thallium significantly diminishes the glass transition temperature from $786 \mathrm{~K}$ in the case of pure $\mathrm{GeS}_{2}$ to $538 \mathrm{~K}$ for the composition $\left(\mathrm{GeS}_{2}\right)_{90} \mathrm{Tl}_{10}$. According to the recent studies [2] during quenching from $1300 \mathrm{~K}$, the maximum content of $\mathrm{Tl}_{2} \mathrm{~S}$ in the glassy alloys in the $\mathrm{Tl}_{2} \mathrm{~S}-\mathrm{GeS}_{2}$ system is $66.7 \mathrm{~mol} . \%$.

Thallium increases the ability of the glass formation with the chalcogenides of Group IV-a elements due to the fact that effectively interacts not only with chalcogen but also with both components of the binary chalcogenide glass. In this case, the glass contains complex structural units which possess all three components. The composition and geometry of the structural units formed in the glass are close to those of individual ternary compounds. The covalent component of the chemical bond in such ternary compounds is higher than for the binary metal chalcogenides.

In the present article the glass formation studies in the quasi-ternary system $\mathrm{Tl}_{2} \mathrm{~S}-\mathrm{In}_{2} \mathrm{~S}_{3}-\mathrm{GeS}_{2}$ are presented for the first time. It is known that the $\mathrm{Tl}_{\mathrm{In}} \mathrm{S}_{2}-\mathrm{GeS}_{2}$ section of this system features quaternary compounds $\mathrm{TlInGe}_{3} \mathrm{~S}_{8}$ [13], TlInGeS ${ }_{4}$ [14], and $\mathrm{TlInGe}_{2} \mathrm{~S}_{6}$ [15]. Therefore, based on the previous research, the goal of our work is to combine the best features of components in one system, when chemical composition allows a modification of properties. We performed absorbance measurements and determined the band gap of the titled glasses. Finally the studies of the photoinduced birefringence have been done to investigate the composition effect. More other, knowledge of the phase diagram allows further for modification (for example by annealing) of the obtained glasses towards to broadening optical features by activate their nonlinear optical properties for the generation of SHG [5] as it was just shown for the system $\mathrm{GeS}_{2}-\mathrm{Ga}_{2} \mathrm{~S}_{3}-\mathrm{Li}_{2} \mathrm{~S}$ [16]. It should be emphasized that such a procedure allows obtaining optical functionality similar to crystals, with much simpler technology and free choice of the shape.

\section{Experimental}

Glass-formation region for the $\mathrm{Tl}_{2} \mathrm{~S}-\mathrm{In}_{2} \mathrm{~S}_{3}-\mathrm{GeS}_{2}$ system was determined by exploration of the synthesized 23 alloys with different composition. The all batches contained high-purity elements (at least 99.99 wt.\%; Aldrich Germany). The precisely calculated amounts of the starting substances were placed into quartz crucible that were evacuated to a precise equal to about $1.33 \cdot 10^{-}$ ${ }^{2} \mathrm{~Pa}$ and soldered. The ingredients were preliminarily synthesized by heating in the oxygen-gas burner flame for the bonding of elementary sulphur under visual control of the reaction process. Then the ampoules were placed in shaft-type furnaces and heated at the rate of $20-30 \mathrm{~K} / \mathrm{h}$ up to $1300 \mathrm{~K}$. Upper parts of the ampoules have been insulated by asbestos rope to avoid splashing the melts during quenching and to minimize the losses for the condensation of the vapor phase on the ampoule walls. The ampoules with the melts were kept at the maximum temperature for $6 \mathrm{hrs}$ and then quenched into cold water.

Characteristic temperatures for the glasses were determined by differential thermal analysis (DSC) at a Paulik-Paulik-Erdey derivatograph with a Pt/Pt-Rh 
thermocouple. The heating rate was equal to about $10 \mathrm{~K} / \mathrm{min}$, with cooling in inertial mode.

Optical transparent measurements were performed at ambient temperature using MDR-208 monochromator with the wavelength determined error $\lambda= \pm 0.1 \mathrm{~nm}$. The samples were cut as parallel-plane plates of $\sim 0.1 \mathrm{~mm}$ thickness with high optical quality surfaces obtained by mechanical polishing.

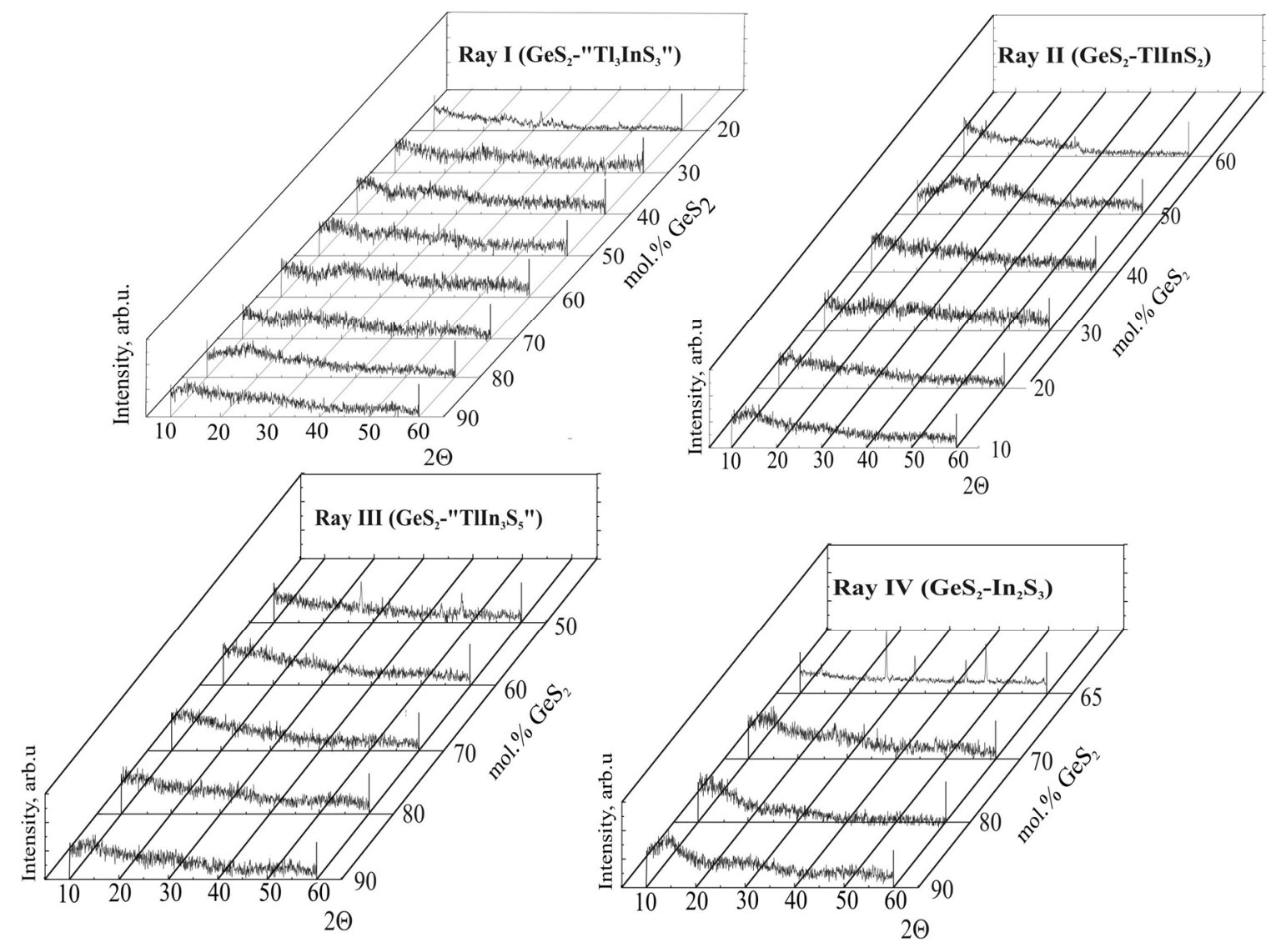

Fig. 1. XRD diffraction patterns of the $\mathrm{Tl}_{2} \mathrm{~S}-\mathrm{In}_{2} \mathrm{~S}_{3}-\mathrm{GeS}_{2}$ glasses along the rays: $\mathrm{I}-\mathrm{GeS}_{2}-{ }^{\prime} \mathrm{Tl}_{3} \mathrm{InS}_{3}$ ', II $-\mathrm{GeS}_{2}-\mathrm{TIInS}_{2}$, III $-\mathrm{GeS}_{2}-{ }^{\prime} \mathrm{TlIn}_{3} \mathrm{~S}_{5}$ ', IV $-\mathrm{GeS}_{2}-\mathrm{In}_{2} \mathrm{~S}_{3}$ (compositions are given in the coordinates of the quasi-ternary system).

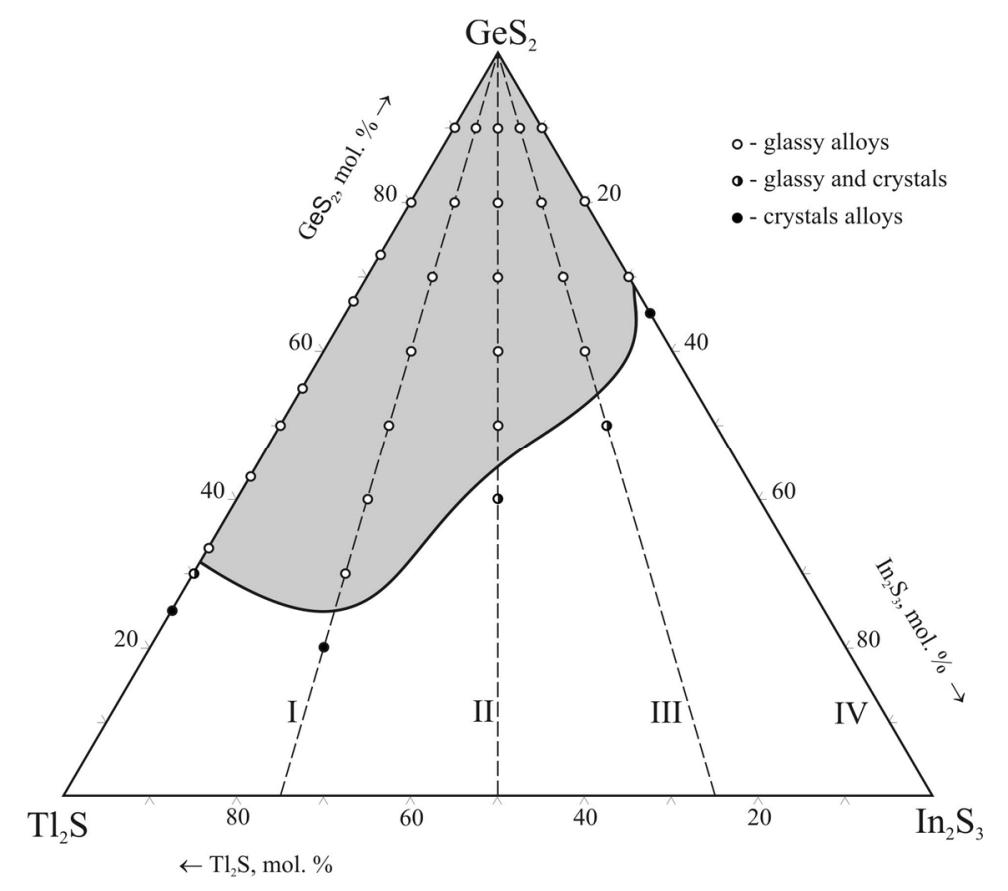

Fig. 2. Glass-formation region (grey area) for the quasi-ternary system $\mathrm{Tl}_{2} \mathrm{~S}-\mathrm{In}_{2} \mathrm{~S}_{3}-\mathrm{GeS}_{2}$. 


\section{Results and discussion}

The structure of all of 23 samples possess different composition, were examined by XRD method, which allowed determining glass formation region. The diffraction patterns are shown at Fig. 1 and follow them the glass-formation region (grey area) in the quasiternary system $\mathrm{Tl}_{2} \mathrm{~S}-\mathrm{In}_{2} \mathrm{~S}_{3}-\mathrm{GeS}_{2}$ was determined, see Fig. 2.

The majority of the prepared samples in the $\mathrm{Tl}_{2} \mathrm{~S}-\mathrm{In}_{2} \mathrm{~S}_{3}-\mathrm{GeS}_{2}$ system are located on five paths that are shown along with the glass-formation region in Fig. 2. All obtained glasses are transparent in the visible spectrum.

Under the selected quenching conditions, the glassy alloys at the boundary sides contain up to $66.7 \mathrm{~mol} . \%$ $\mathrm{Tl}_{2} \mathrm{~S}$ [8] or $30 \mathrm{~mol} \% \mathrm{In}_{2} \mathrm{~S}_{3}$. The compositions of the alloys inside the concentration triangle were located on three paths. The range of the glassy alloys along path $I$ $\left(\mathrm{GeS}_{2}-{ }^{\prime} \mathrm{Tl}_{3} \mathrm{InS}_{3}\right.$ ' (75 mol.\% $\left.\mathrm{Tl}_{2} \mathrm{~S}-25 \mathrm{~mol} . \% \mathrm{In}_{2} \mathrm{~S}_{3}\right)$ ) is $30-100$ mol.\% $\mathrm{GeS}_{2}$, along path II $\left(\mathrm{GeS}_{2}-\mathrm{TlInS}_{2}\right.$ (50 mol.\% Tl $\left.\mathrm{Tl}_{2} \mathrm{~S}-50 \mathrm{~mol} . \% \mathrm{In}_{2} \mathrm{~S}_{3}\right)$ ) is $50-100 \mathrm{~mol} . \%$ $\mathrm{GeS}_{2}$, and along path III $\left(\mathrm{GeS}_{2}-{ }^{-} \mathrm{TlIn}_{3} \mathrm{~S}_{5}\right.$ ' $\left(25 \mathrm{~mol} \% \mathrm{Tl}_{2} \mathrm{~S}\right.$ $\left.-75 \mathrm{~mol} . \% \mathrm{In}_{2} \mathrm{~S}_{3}\right)$ ) is 60 - $100 \mathrm{~mol} . \% \mathrm{GeS}_{2}$.

Typical temperatures of the glasses (glass formation temperature, crystallization and melting point) that were

Table 1

Characteristic temperatures, band gap energy and characteristic energy of the glassy alloys for the quasi-ternary system $\mathrm{Tl}_{2} \mathrm{~S}-\mathrm{In}_{2} \mathrm{~S}_{3}-\mathrm{GeS}_{2}$.

\begin{tabular}{|c|c|c|c|c|c|c|c|c|c|}
\hline \multirow{2}{*}{ № } & \multicolumn{3}{|c|}{ Alloy composition, mol.\% } & \multirow{2}{*}{$\mathbf{T}_{\mathrm{g}}, \mathbf{K}$} & \multirow{2}{*}{$\mathbf{T}_{\mathbf{c}}, \mathbf{K}$} & \multirow{2}{*}{$\mathbf{T}_{\mathrm{m}}, \mathbf{K}$} & \multirow{2}{*}{$\mathbf{T}_{\mathrm{gr}}$} & \multirow{2}{*}{$E_{g}, e V$} & \multirow{2}{*}{$\Delta_{0}, \mathrm{eV}$} \\
\hline & $\mathrm{Tl}_{2} \mathrm{~S}$ & $\operatorname{In}_{2} S_{3}$ & $\mathbf{G e S}_{2}$ & & & & & & \\
\hline \multicolumn{10}{|c|}{ Trace I } \\
\hline 1 & 7.5 & 2.5 & 90 & 476 & 675.707 & - & - & 2.17 & 0.06 \\
\hline 2 & 15 & 5 & 80 & 511 & 669 & 777,833 & 0.66 & 2.18 & 0.065 \\
\hline 3 & 22.5 & 7.5 & 70 & 483 & 690.719 & 795 & 0.61 & 2.10 & 0.055 \\
\hline 4 & 30 & 10 & 60 & 498 & - & 835 & 0.60 & 2.10 & 0.06 \\
\hline 5 & 45 & 15 & 40 & 484 & 580 & 728 & 0.66 & - & - \\
\hline \multicolumn{10}{|c|}{ Trace II } \\
\hline 6 & 5 & 5 & 90 & 655 & 796 & 951 & 0.69 & 2.23 & 0.055 \\
\hline 7 & 10 & 10 & 80 & 633 & 757 & 933 & 0.68 & 2.23 & 0.06 \\
\hline 8 & 15 & 15 & 70 & 626 & 731 & 922 & 0.68 & - & - \\
\hline 9 & 20 & 20 & 60 & 612 & 739.755 & 912 & 0.67 & 2.28 & 0.05 \\
\hline 10 & 25 & 25 & 50 & 580 & 714 & 840 & 0.69 & - & - \\
\hline \multicolumn{10}{|c|}{ Trace III } \\
\hline 11 & 2.5 & 7.5 & 90 & 642 & 783 & 1050,1095 & 0.61 & 2.25 & 0.05 \\
\hline 12 & 5 & 15 & 80 & 638 & 780 & 914,1016 & 0.69 & 2.25 & 0.05 \\
\hline 13 & 7.5 & 22.5 & 70 & 568 & 733 & 908 & 0.63 & 2.26 & 0.05 \\
\hline 14 & 10 & 30 & 60 & 590 & 612.723 & 859 & 0.68 & - & - \\
\hline \multicolumn{10}{|c|}{ Trace IV } \\
\hline 15 & - & 10 & 90 & 648 & 768 & 1035 & 0.63 & 2.12 & 0.06 \\
\hline 16 & - & 20 & 80 & 601 & 710.815 & 997,1029 & 0.60 & 2.17 & 0.065 \\
\hline 17 & - & 30 & 70 & 590 & 651.811 & 1018 & 0.58 & 2.22 & 0.07 \\
\hline
\end{tabular}

Table 2

Chosen set of glass samples for optical investigations of absorption coefficient to evaluate band gap

\begin{tabular}{|c|c|}
\hline Sample Nr & Composition \\
\hline 1 & $7.5 \% \mathrm{Tl}_{2} \mathrm{~S}-90 \% \mathrm{GeS}_{2}-2.5 \% \mathrm{In}_{2} \mathrm{~S}_{3}$ \\
\hline 2 & $5.0 \% \mathrm{Tl}_{2} \mathrm{~S}-90 \% \mathrm{GeS}_{2}-5.0 \% \mathrm{In}_{2} \mathrm{~S}_{3}$ \\
\hline 3 & $2.5 \% \mathrm{Tl}_{2} \mathrm{~S}-90 \% \mathrm{GeS}_{2}-7.5 \% \mathrm{In}_{2} \mathrm{~S}_{3}$ \\
\hline 4 & $15 \% \mathrm{Tl}_{2} \mathrm{~S}-80 \% \mathrm{GeS}_{2}-5.0 \% \mathrm{In}_{2} \mathrm{~S}_{3}$ \\
\hline 5 & $10 \% \mathrm{Tl}_{2} \mathrm{~S}-80 \% \mathrm{GeS}_{2}-10 \% \mathrm{In}_{2} \mathrm{~S}_{3}$ \\
\hline 6 & $5.0 \% \mathrm{Tl}_{2} \mathrm{~S}-80 \% \mathrm{GeS}_{2}-15 \% \mathrm{In}_{2} \mathrm{~S}_{3}$ \\
\hline
\end{tabular}



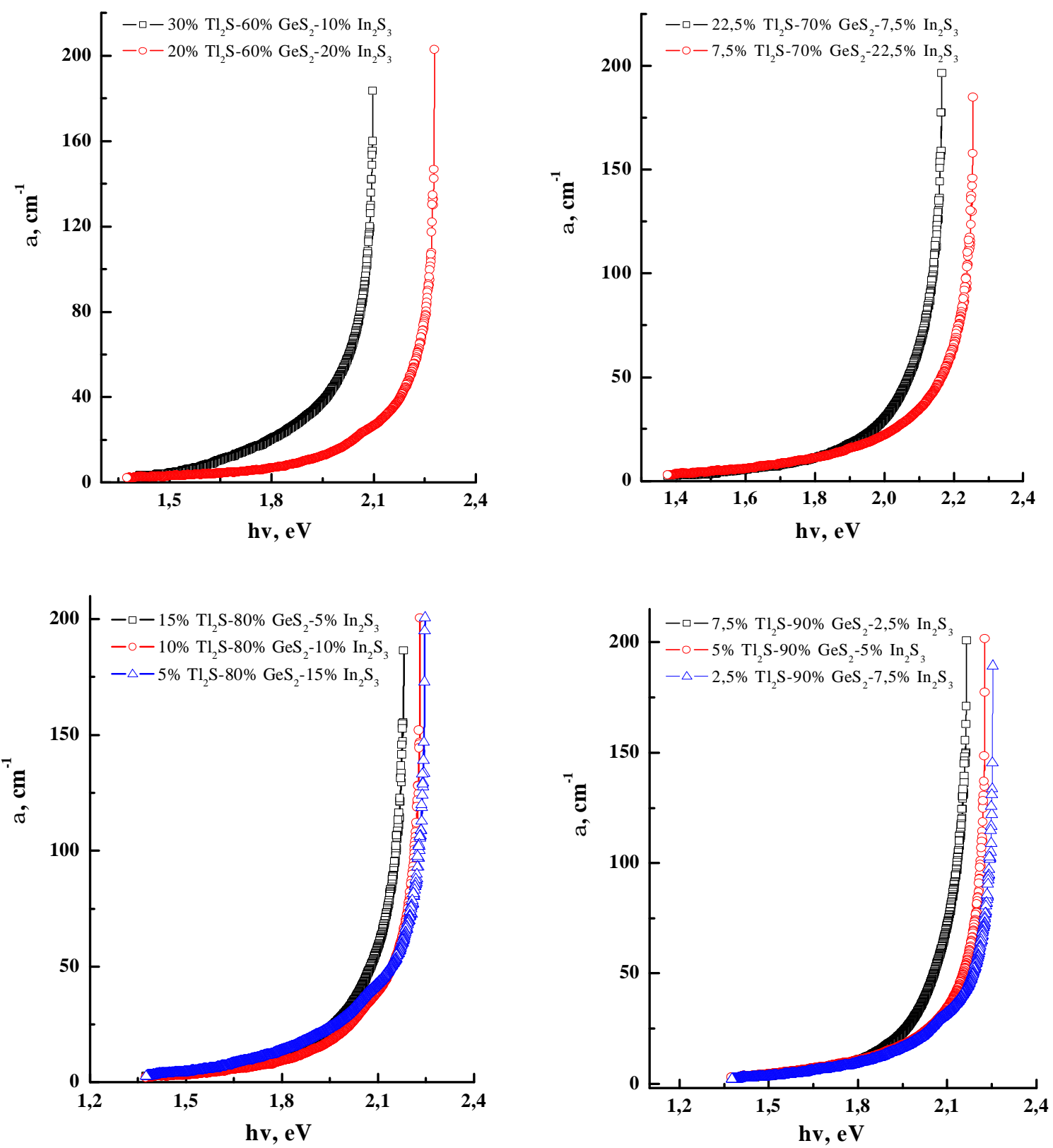

Fig. 3. Dependence of the absorption coefficient on the incident light energy for the glassy alloys $\mathrm{Tl}_{2} \mathrm{~S}-\mathrm{In}_{2} \mathrm{~S}_{3}-\mathrm{GeS}_{2}$ at $300 \mathrm{~K}$.

determined from DTA results are presented in Table 1.

The glass formation temperature decreases with the increasing $\mathrm{GeS}_{2}$ content (except for the glasses on trace I) and are ranged within $476-655 \mathrm{~K}$. The glassy alloys $1,3,9,14,16,17$ feature two exothermal crystallization effects. The melting points of the studied glasses lay in the region of 728-1095 K. The DTA results of the alloys along ray IV $\left(\mathrm{GeS}_{2}-\mathrm{In}_{2} \mathrm{~S}_{3}\right)$ agree with the data in [2]. Qualitative analysis of the thermal stability of the glasses was estimated by the calculated reduced glass formation temperature that correlates well the glass formation temperature $T_{g}$ and the melting point $T_{m}$ of the glassy alloys $\left(\mathrm{T}_{\mathrm{gr}}=\mathrm{T}_{\mathrm{g}} / \mathrm{T}_{\mathrm{m}}\right)$.

The values of the reduced glass formation temperature listed in Table 1 indicate high affinity of the alloys to glass formation.

\section{Optical Properties}

Optical investigations of absorption coefficient to evaluate band gap were performed for chosen set of glass samples (numbers used for optical measurements) Table 2:

Typical spectral dependences of the absorption coefficient of the glassy alloys of the $\mathrm{Tl}_{2} \mathrm{~S}-\mathrm{In}_{2} \mathrm{~S}_{3}-\mathrm{GeS}_{2}$ system with various ratios of $\mathrm{Tl}_{2} \mathrm{~S}, \mathrm{GeS}_{2}$ and $\mathrm{In}_{2} \mathrm{~S}_{3}$ at ambient temperature are presented in Figs. 3, 4.

Such drastic enhancement of $\alpha$ for the light with $h v>1.8 \mathrm{eV}$ confirms a domination of the absorption caused by inter-band transitions with respect to scattering. 


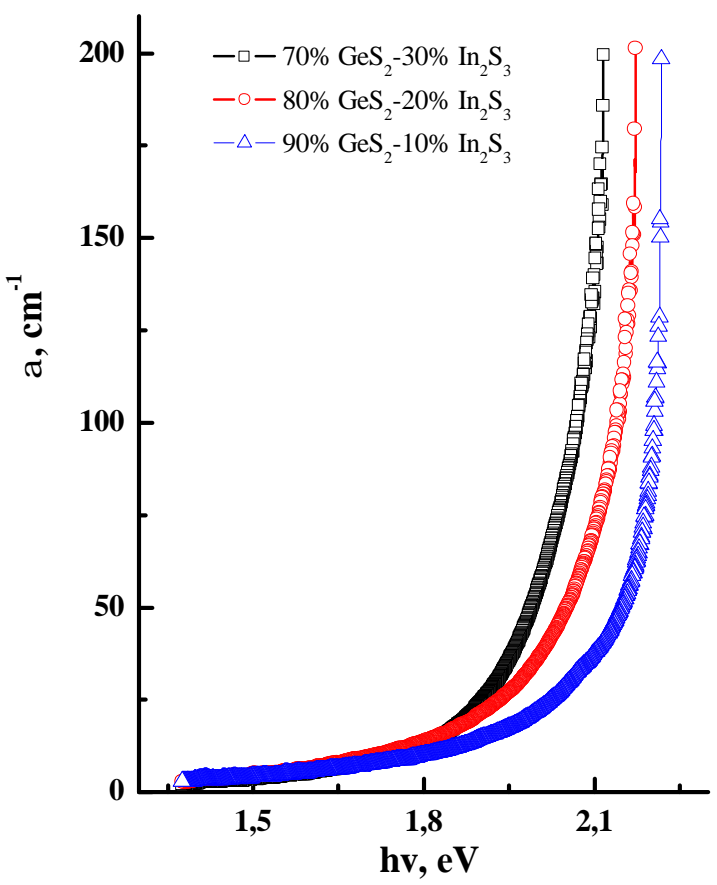

Fig. 4. Spectral dependence of the absorption coefficient near the fundamental energy gap for the glasses of the $\mathrm{In}_{2} \mathrm{~S}_{3}-\mathrm{GeS}_{2}$ system at $300 \mathrm{~K}$.

The approximation of the $\alpha(h v)$ plots in the region of $h v>2.1 \mathrm{eV}$ to linear dependences witnesses the adherence to Urbach's rule which is typical for disordered semiconductors [5]:

$$
\alpha(h v) \sim \exp \left(-\frac{h\left(v_{0}-v\right)}{\Delta_{0}}\right),
$$

where $\Delta_{0}$ is the characteristic energy with values of $\sim 0.05-0.07 \mathrm{eV}$ and estimates of $E_{g}$ at the level of $\alpha=200 \mathrm{~cm}^{-1}$ what is listed in Table 1 .

Parameter of $\Delta_{0}$ is a characteristic energy directly related to local disorder for determination of the respective absorption edge or to the degree of the crystalline disorder. Thus, according to Urbach's rule, high $\Delta_{0}$ values mean that the glassy alloys of the $\mathrm{Tl}_{2} \mathrm{~S}-\mathrm{In}_{2} \mathrm{~S}_{3}-\mathrm{GeS}_{2}$ system present intrinsic defective semiconductors, with electronic structure analogous to disordered systems.

The band gap energy of the glasses of the $\mathrm{Tl}_{2} \mathrm{~S}-\mathrm{In}_{2} \mathrm{~S}_{3}-\mathrm{GeS}_{2}$ system (Table 1) is varied with the change of the ratio of the modifiers $\left(\mathrm{Tl}_{2} \mathrm{~S}, \mathrm{In}_{2} \mathrm{~S}_{3}\right)$.

\section{Conclusions}

Glass-formation region in the quasi-ternary system $\mathrm{Tl}_{2} \mathrm{~S}-\mathrm{In}_{2} \mathrm{~S}_{3}-\mathrm{GeS}_{2}$ was investigated by X-ray phase analysis. The minimum concentration of the glassforming component $\mathrm{GeS}_{2}$ is $30 \mathrm{~mol} \%$. Characteristic temperatures of the glasses of the system were determined, and the reduced glass-formation temperature was calculated. Obtained results show high affinity of the alloys to glass formation. Optical absorption of obtained glasses was investigated. It was determined that optical bandgap energy varies from 2.10 to $2.28 \mathrm{eV}$.

Tsisar O.V. - PhD, Researcher;

Piskach L.V. - PhD, Associate Professor, Department of Inorganic and Physical Chemistry;

Parasyuk O.V. - PhD, Associate Professor, Department of Inorganic and Physical Chemistry;

Zamurujeva O.V. - PhD, Senior Lecturer in the Department of Experimental Physics and Information and Measurement Technologies;

Myronchuk G.L. - Dr. Sci., Professor, Department of Experimental Physics and Information-Measurement Technologies;

Piasecki M.V. - Researcher.

[1] G. Boudebs et. al., Optics Communications 219, 427 (2003) (doi: 10.1016/S0030-4018(03)01341-5).

[2] O.V. Tsisar et. al., Journal of Materials Science: Materials in Electronics 28(24), 19003 (2017) (doi: 10.1007/s10854-017-7854-x).

[3] O.V. Zamurueva, et. al., Optical Materials 37(C), 614 (2014) (doi: 10.1016/j.optmat.2014.08.004).

[4] H.Z. Tao et. al., Solid State Communications 138, 485 (2006) (doi: 10.1016/j.ssc.2006.04.031).

[5] A.H. Reshak et. al., Journal of Applied Physics 116(14), 143102 (2014) (doi: 10.1063/1.4897457).

[6] Yan Zhang, et al., Optics and laser technology 108, 306 (2018) (doi: 10.1016/j.optlastec.2018.07.002).

[7] Prabhudutta Pradhan, R. Naik, N. Das, A. K. Panda, Optics and laser technology 96, 158 (2017) (doi: 10.1016/j.optlastec.2017.05.033).

[8] A.H. Kevshyn, et al., Glass Physics and Chemistry 36(1), 27 (2010) (doi: 10.1134/S1087659610010050).

[9] Tao Haizheng et al., Journal of Non-Crystalline Solids 354, 1303-1307 (2008) (doi: 10.1016/j.jnoncrysol.2007.01.103).

[10] R. Dedryvère, P.E. Lippens, J.C. Jumas, I. Lefebvre, Solid State Physics 3, 267 (2001) (doi: 10.1016/S12932558(00)01137-7).

[11] Lin Chang-Gui et al., Acta Physica Sinica-Chinese Edition 64(5), 054208 (2015) (doi: 10.7498/aps.64.054208).

[12] I.M. Fodchuk, S.M. Novikov, I.V. Yaremchuk, Applied Optics B120-B125 (2016), (doi: 10.1364/AO.55.00B120). 
O.V. Tsisar, L.V. Piskach, O.V. Parasyuk, O.V. Zamurujeva, G.L. Myronchuk, M. Piasecki

[13] O. Y. Khyzhun et al., Materials Chemistry and Physics 204, 336(2018) (doi: 10.1016/j.matchemphys.2017.10.054).

[14] Yohannan Jinu P., Vidyasagar Kanamaluru, Journal of Solid State Chemistry 238, 291 (2016) (doi: 10.1016/j.jssc.2016.03.045).

[15] O.Y. Khyzhun et al., Journal of Alloys and Compounds 735, 1694 (2018) (doi: 10.1016/j.jallcom.2017.11.257).

[16] Qiming Liu \& Peng Zhang, Scientific Reports 4, 5719 (2014) (doi: 10.1038/srep05719).

\section{О.В. Цісар ${ }^{1}$, Л.В. Піскач ${ }^{1}$, О.В. Парасюк ${ }^{1}$, О.В. Замуруєва ${ }^{1}$, Г.Л. Мирончук ${ }^{1}$ М. Пясецький ${ }^{1,2}$ \\ Склосистема $\mathrm{Tl}_{2} \mathrm{~S}-\mathrm{In}_{2} \mathrm{~S}_{3}-\mathrm{GeS}_{2}$ як новітні перспективні матеріали для фотоніки}

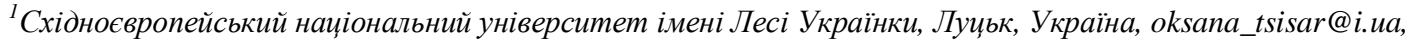
piskach.lyudmyla@eenu.edu.ua, zamurueva.o@gmail.com, myronchuk.halyna@eenu.edu.ua

${ }^{2}$ Iнститут фізики, Університет Й. Длугоша в Ченстохові, Ченстохова, Польща, piaseckimw@gmail.com

Встановлено, що мінімальний вміст складоутворюючого компонента $\mathrm{GeS}_{2}$ дорівнює 30 мол.\% (досліджували набір 23 різних сплавів з різним складом). Встановлено взаємозв'язок між структурними властивостями, термічними параметрами (температура скла, температури кристалізації та плавлення) та оптичними спектрами поглинання. Експериментально досліджені температури, енергія розриву смуг та характерна енергія склоподібних сплавів для системи $\mathrm{Tl}_{2} \mathrm{~S}-\mathrm{In}_{2} \mathrm{~S}_{3}-\mathrm{GeS}_{2}$.

Ключові слова: халькогенідні окуляри; оптичні властивості; дифрактограми XRD.
} 